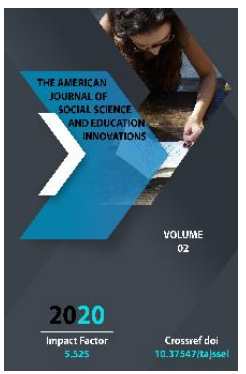

\title{
Narrative Poetry And Poetry Only Couplets Of Persian- Tadjik Literature Of X-Xi Centuries
}

\author{
Akhmedova Dilorom \\ Samarkand State University Researcher, Uzbekistan
}

Journal Website:

http://usajournalshub.c

om/index,php/tajssei

Copyright: Original content from this work may be used under the terms of the creative commons attributes 4.0 licence.

\section{ABSTRACT}

This article is devoted to the study of the poetry only couplets genre in the Persian-Tadjik literature of the $\mathrm{X}-\mathrm{X} 1$ centuries, reveals the content of the poetry only couplets genre, the lives of poets, the moments of the poets' real personal and real life.

\section{KEYWORDS}

The poetry only couplets genre, Persian-Tadjik literature, court poets, biographic poetry only couplets genre, praising person in poetry, life of poets.

\section{INTRODUCTION}

Many works of the poetry only couplets genre are written in connection with the life of the poets, the events and happenings in their lives. Some of them reflected special moments related to the personal and real life of the poets. Some moments in the life of the poets are usually expressed within biographic poetry only couplets and when they write from praising hero demanding the most important things of life. The poetry only couplets of demand and freedom cover very important moments in the life of poets, as 
well as valuable documents, so it is important to study the state of their biographic. In this case, the poetry only couplets genre is a unique document, which, first of all, reflects the aspects of the poet's life.

\section{LITERATURE REVIEW}

In the official verse, the poet could not describe the "details" of his life. It is true that he sometimes had the opportunity and "right" to mention his condition in the poem, but in general, he would express it in accordance with the traditions of the royal palace. On the poetry only couplets genre, these "details" of the poet's life are used clearly and naturally, without any usage or gestures. We will illustrate this point with a couple of examples. In his first separate verse, Abu Shakur Balkhi says that there is no doubt that it will be the poetry only couplets poem:

Rafiqoni man bo mayu nozu ne'mat, Manam orzumandi yakto zag'ora[4,146]. Definition: My friends are full of wine and treats, and I crave a loaf of bread.

The poet addresses some of his praising person in poetry and tells him about his life of poverty, that a group of other people, such as his colleagues, live a dark, peaceful life, where he lives with the dream of a loaf of bread. This desire is expressed in a concrete way, reflecting the poet's life in need, through the image of "corn" bread. This image may have shown the poet's poverty and malnutrition more severely than ever.

But in this case, the author of "Ofarinnoma" describes himself as in need of a loaf of bread, which indicates that his living conditions are bad, at least at some point in his life.

He also complained to a praising person in poetry:
Bo ne'mati tamom ba dargohat omadam, Imro'z bo gavozeyu cho'be hameravam[4,143] Definition: I have come to you with a blessing, and today I am leaving with a piece of wood.

\section{ANALYSIS}

The poet states that his living conditions were good when he came to service with such a complaint, but he became poor and bankrupt when he left.

It should be noted that such documents are related to the praise and protest of statesmen by poets, and in this service more reflect their difficult life, their failure to achieve their goals, which has become the main theme of biographic poems. Especially the poetry only couplets are full of such complaint motives.

Even the poetry only couplets of the famous poet Farolavi have embraced such complaints. Farolavi also exaggerated in his description of his poor life and bankruptcy, informing praising person in poetry that he drank water from the "munda" (old earthenware bowl) in spite of his many phases:

Ravo nabvad, ki bo in fazlu donish

Buvad shurbam hame doim zi munda[4,72].

Definition: With so much phase knowledge, my drinking pot can't be made of old pottery.

Here, too, the image of "munda" symbolizes poverty in the verses of Abu Shakur, such as "cane", "wood" (wooden work) and "corn" bread. Through these images, the shortcomings in the lives of the poets are illustrated with the help of certain details, such as the documents of their occupation. We also see this in Rabanjani's account of a real adventure that took place during the month of Ramadan when he went to the 
market in Marsmanda to buy sheep (which took place around Bukhara):

Raftam ba mohi ro'za bozori Marsmanda,

To go'sfand oram, farbeh kunam ba xona[4,206].

Definition: During the month of Ramadan, I went to the market in Marsmanda to fetch sheep and feed them at home.

This factual scene of the poet's life is described as a vital fact, without being included in the image.

The poets described such "details" of life not only in the narration of their lives, but also in the depiction of people's lives and real events of the time. For example, in this verse of Khusrawani, it is stated that people, especially children, climbed on the roofs of houses and drove the troubled dervishes out of their homes with stones and sticks:

Ba xosa kunun, k-az qibali rondani darvesh

Bar bom shaved har kas bo sangu faloxan[4,188].

Definition: Especially now that everyone is coming out of the roof with stones and sledgehammers to chase the dervish people.

This tablet is a very important document in the study of the history of darvishism (mysticism). It is clear from this that in spite of the development and prestige of dervishism in the tenth century, in fact, the influence of this category among the masses was small.

As described in the following verse, Rudaki's visit to a village where the owner had no account on his way to Nishapur is also significant as a historical document:

Dar rohi Nishopur didam dehe xub, Angashbai o'ro na adad budu na marra(108)

Definition: I saw a good village on the way to Nishapur, the number of its owner was not known, nor the finish.
We know from this verse of Tarkiy Keshi Ayloqi that the Armenian people did not eat wheat bread at that time:

Guftam, ki armanist magar Xocha Bulamid, K-o' noni gandumin naxo'rda chuz, ki sangula[4,112]

Definition: I said that Hoja Bulamid is an Armenian who only ate sangula (a type of plant) and never ate wheat bread in his life.

These are the poetry only couplets of the poets of that period, which cover the life events with small details and plates, which in general show that the poetry only couplets have many and wide connections with real events and the richness of the content of this genre in their works.

These poetry only couplets also reflect the connection and relationship of the event between the poets and their themes, providing valuable material in the study of the issue of the poet and the ruler.

The other part of the documentary poetry only couplets is devoted to various large and small events and happenings that took place during the life of the poets. The events on the poetry only couplets belong to different areas of the history of the period: in one the poetry only couplets one event of social or political life is described, while in another it is told about an event of cultural life. We get useful information from the poetry only couplets, especially on cultural and scientific-literary life of the period - such as the construction of palaces and palaces, mosques and madrasas, the hymns of scholars or laments about them. In general, the poetry only couplets are full of descriptions of various events and happenings, as well as documents relating to various spheres of life at the time in which they were written. 
Certain moments of the poet's life were described in different ways. For example, the praise of some people in a time when the ugly traits and habits of the person being ridiculed may be included in the hymn, or the description of certain cultural and scholarly figures may be accompanied by information about their lives and activities. In another play, he writes about the political and social activities of a statesman, mentions various events in the political, social, cultural, scientific and literary life of the time, builds various religious and educational institutions, builds private buildings and celebrates the weddings of celebrities, laments about their arrival or death, etc. are documents of life of a certain historical period, taken from the poetry only couplets of the poets of that period.

While reading them, the reader travels into the world of life events and happenings, coming face to face with life facts and documents. These events are not the product of the poet's own imagination and fabric, but the real life events that the poets have seen, observed or experienced in real life without modification. Hence, the poet is a perfect document copyist in the transmission of events and happenings on the poetry only couplets. Figuratively speaking, they are at the forefront of the reality of life.

\section{DISCUSSION}

The biographic poetry only couplets are also documentary poems that reflect the original state of the poets 'lives. Therefore, they are recognized as reliable documents in the restoration of the scientific status of poets. It is clear from this that much poetry only couplets have a documentary character. Therefore, they can also be called documentary poetry only couplets. In general, the poetry only couplets are real-life events and phenomena, as well as documents. In them, not the image of life, but itself, is manifested without makeup. On the poetry only couplets, life is not artistically reflected through images, but directly through living and real people, various events and happenings, and their facts and documents.

It is clear from these words that the connection between the contents of the poetry only couplets and the real reality has been largely realized through documentation. Although this image style of reality is close to our realism, but it is not, of course. Nevertheless, the poetry only couplets are more in touch with real life than with all the works of classical poetry.

Thus, the praising poet becomes a truthful poet who, knowingly or unknowingly, expresses the truth in writing the poetry only couplets. The palace poet travels on the poetry only couplets not only to depict life within the palace and its representatives, but also to the environment outside the palace.

He looks at a wide-ranging reality outside the palace through the window of the poetry only couplets poetry, and traces the lifestyles and activities of different categories of people on paper. In such cases he is embodied not as a court poet, but as a creator outside of him. His writings reflect the lives of people who had no relationship with the palace of rulers, and with their content belong to poetry outside the palace. Most importantly, these poems are far from the artificiality and falsity of the poetry in the palace. They are dominated by seeing reality and realism.

On the poetry only couplets, the social circle of the applicants also expanded considerably, encompassing representatives of categories 
not related to the court of rulers and their service. In addition to the people of the palace, the poet praises and speaks about the life and profession of the non-civil servants. In the poetry only couplets devoted to the expression of the poets' ideas, it is well known that although the addressees are vaguer, they are directed to the masses. There is no doubt that this meant the audience inside and outside the palace. Even in the mention of the addressee, moral poetry, including our exhortations, is more public.

On the poetry only couplets, the social circle of the applicants also expanded considerably, encompassing representatives of categories not related to the court of rulers and their service. In addition to the people of the palace, the poet praises and speaks about the life and profession of the non-civil servants. In the poetry only couplets devoted to the expression of the poets' ideas, it is well known that although the addressees are vaguer, they are directed to the masses. There is no doubt that this meant the audience inside and outside the palace. Even in the mention of the addressee, moral poetry, including our exhortations, is more public.

This phenomenon of the poetry only couplets, aimed at a wide range of peoples, took their theme and content out of the palace environment and connected them to real life. The poetry only couplets thus turn the praisers of the palace owners into one man, that is, from the main praising person $n$ poetry - the king poet, to the poet of the broad people. In this connection, the scope of the theme and content of his poetry only couplets poems also expands, meeting as much as possible the demands of folk groups and categories, representing their vital interests.
Finally, another notable feature of the poetry only couplets is that their attitudes toward events and happenings are expressed in the form of impressions, responses.

The poet is under the influence of various events and happenings in life, especially grieving over unpleasant events, angry at the abominable actions of some aristocratic people, ungodly habits of some of his colleagues, such as greed, jealousy, complaining about the shortcomings of his life. At the same time, he blames those who are ignorant of the profession, or rebels against the cruelty of the universe towards the scholars, and so on. In these cases, he takes a pen in his hand under the deep influence of life events and turns to poetry at the request of the environment. This poem is recited almost constantly in the poetry only couplets genre.

In this way, the poetry only couplets become relevant in its subject and content, and even, in some cases, acquires the character of a lover and badiha. This also indicates a direct connection of real reality with this genre. In general, the poetry only couplets are often told in the form of badiha with the occurrence of events, the necessity of the situation that has taken place in life.

Therefore, the poetry only couplets can also be recognized as a badiha genre. In most cases, the recitation of the poetry only couplets as a quickly created poem or badiha is evident not only in their content, but also in their emptiness from the inevitable art and word art.

As far as we know, badiha poems are usually less decorated with fine arts because they are said and written quickly. In Badiha, the poet does not find the opportunity and opportunity 
to decorate poetry through the arts, or does not consider it necessary, so he describes the content in a "naked" way. It is self-evident that Badiha poems are less widely used in the arts, as they are often recited in the poetry only couplets form. This can be seen, for example, when Shakir Bukharai said filbadoha

on the following the poetry only couplets:

Xush on nabidi G'or chi bo do'stoni yakdila, Geti ba orom-andarun, machlis ba bongu valvala.

Machlis paroshida hama, meva xaroshida hama,

Nuql biposhida hama, bo chokaron karda yala[4, 86].

Definition: That Cave wine is enjoyed by allied friends. In times of peace in the world, the assembly is busy with noise and commotion. Meetings, fruit, and treats were served on all sides.

However, the richness of the poetry only couplets of the poets of the X-XII centuries attracted the attention of Tadjik literary critics who studied the palace literature of this period and the works of its individual representatives. Researchers have limited themselves to showing the number of poetry only couplets and the level of quantity of works of this genre in the offices of poets, and have not paid attention to its content.

\section{CONCLUSION}

However, the poetry only couplets are not only studied in terms of numbers, but also in terms of their rich and colorful content. These important and valuable aspects of the poetry only couplets, which have been overlooked by scholars, are that it has not yet been studied in depth as a genre, and that the characteristics of genre have not been defined.
Therefore, the researcher of the palace literature of XI-XII centuries A.Abdulloev, in his pamphlet devoted to the life and works of Adib Sabir Tirmidhi, which covers more poetry only couplets than the devons of other contemporary poets, analyzes the ideological content of the poet's work, but remained silent about their genre affiliation [3]. Significant and valuable works of the poetry only couplets in terms of content have been used in literary research beyond their own genre.

This shortcoming in the study of the poetry only couplets genre of our literature was eliminated only in recent years, more precisely in the dissertation research of Sh. Yormuhammedov on the poetry only couplets of Anvari. But it is well known that the advantage of such a genre theme and content of the poetry only couplets is not peculiar to Anvar's work, but is also observed on the poetry only couplets of other poetic poets of those centuries.

\section{REFERENCES}

1. Abdulgani Mirzoev. Propagation of science and poetry Sezdah article.Dushanbe: Irfon, 1977.

2. Abu'abdullah Rudaki. Nasimi Mo'liyon.Dushanbe: Adib, 1999.

3. Ahmad Abdulloev. Life and work of Adib Sabiri Tirmidhi. -Dushanbe: Donish, 1983

4. Ash'ari hamasroni Ro'dakī. -Monday: Adib, 2007.

5. Yormuhamedov Sh.R. Genre kita v tvorchestvo Anvari Abevardi. - Dushanbe, 2011.

6. Manuchehrii Domgoni. Osori muntaxab. Dushanbe: Donish, 1974.

7. Sa'diev S. Samarkand Literary Center of History.-Tashkent: National Encyclopedia of Uzbekistan, 2012. 
8. Sa'diev S. Doir ba maqomi jamiiyatii shoir dar asri X. -Dushanbe: Sadoi Sharq, 1977, №3.

9. Mirziyoev Sh.M. When literature, art and culture live, the nation and the people, the whole of humanity lives in peace. Congratulations of the President of the Republic of Uzbekistan Sh. Mirziyoyev to the participants of the international conference "Current issues of international study and promotion of Uzbek classical and modern literature". www. habar.uz

10. Tursunov U. O'rinboev B. History of Uzbek literary language. Tashkent, “O'qituvchi” 1982. 